\title{
Diagnosis and management of heparin-induced thrombocytopenia
}

\author{
[Le diagnostic et le traitement de la thrombopénie induite par l'héparine]
}

Emmanuel de Maistre MD, ${ }^{*}$ Yves Gruel MD PhD, $†$ Dominique Lasne PhD

Purpose: To review recent developments in the pathogenesis, clinical features, laboratory testing and treatment of heparininduced thrombocytopenia (HIT).

Methods: Narrative review of the literature, including relevant papers published in English or French.

Principal findings: Although the prevalence of HIT has decreased with the widespread use of low molecular weight heparin in the past ten years, HIT remains a life-threatening prothrombotic state. This immune adverse event due to heparin-dependent antibodies that bind to chemokines (such as platelet factor 4) induces platelet activation and hypercoagulability. Heparin-induced thrombocytopenia can be complicated by thrombosis even after withdrawing heparin, explaining why substituting heparin with an alternative anticoagulant (danaparoid, lepirudin, argatroban) is always necessary. However, management of these alternative treatments is difficult, and in some patients there is the risk of withdrawing heparin without taking the time to diagnose HIT properly on the basis of clinical and laboratory findings (evolution of platelet count, laboratory testing such as antigen assays and platelet activation tests).

Conclusions: Management of HIT has become easier in recent years with the development of more specific and sensitive laboratory tests and new antithrombotic drugs. However, the diagnosis of HIT is often difficult, and it remains very important to investigate this adverse reaction systematically in every patient treated with heparin who develops thrombocytopenia.

Objectif: Revoir l'évolution de la pathogenèse, des caractéristiques cliniques, des tests de laboratoire et du traitement de la thrombopénie induite par l'héparine (TIH).

Méthode: Une revue descriptive de la littérature, incluant les articles pertinents publiés en anglais ou en français.

Constatations principales: Quoique la prévalence de $\mathrm{TIH}$ ait diminué avec l'usage répandu de l'héparine de bas poids moléculaire au cours des dix dernières années, la TIH demeure un état prothrombotique grave. Cet événement immunitaire indésirable, causé par des anticorps reliés à l'héparine qui se lient aux chimiokines (comme le facteur plaquettaire 4), induit l'activation des plaquettes et l'hypercoagulabilité. La TIH peut être compliquée par une thrombose même après le retrait de l'héparine, ce qui explique pourquoi la substitution de l'héparine par un autre anticoagulant (danaparoïde, lépirudine, argatroban) est toujours nécessaire. Cependant, l'utilisation de ces traitements de remplacement est difficile, et chez certains patients, il y a le risque de retirer l'héparine sans prendre le temps de diagnostiquer correctement la TIH d'après les signes cliniques et les résultats de laboratoire (évolution de la numération plaquettaire, tests immunologiques et fonctionnels).

Conclusion : Le traitement de la TIH est maintenant plus facile avec le développement de tests de laboratoire plus spécifiques et plus sensibles et de nouveaux médicaments antithrombotiques. Mais le diagnostic de $\mathrm{TIH}$ est souvent difficile à poser et il demeure très important de rechercher cette réaction indésirable de façon systématique chez chaque patient traité avec de l'héparine chez qui se développe une thrombopénie.

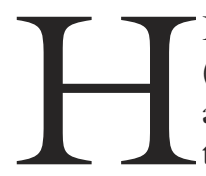
EPARIN-INDUCED thrombocytopenia (HIT) is a prothrombotic disorder, initiated by heparin treatment and related to antibody-mediated platelet activation leading to thrombin generation and thrombotic complications. A fall in platelet count during heparin therapy is the most common feature of this syndrome, and this occurs more frequently with unfractionated heparin (UFH; affecting about $1 \%$ of patients) than with low molecular weight heparin (LMWH; frequency of about $0.1 \%$ ). The risk of HIT is lower in the medical context (less than 1\%) than in cardiac or orthopedic surgery (3 to $5 \%) .{ }^{1}$ The high levels of morbidity and mortality are due to thrombotic com-

From the Laboratoire d'Hématologie-Hémostase, ${ }^{*} \mathrm{CHU}$ Dijon; Dijon; the Laboratoire d'Hématologie-Hémostase, $\dagger$ CHU Tours; Tours; and the Laboratoire d'Hématologieł, Hôpital Necker, Paris, France.

Address correspondence to: Dr. Emmanuel de Maistre, Laboratoire d'Hématologie-Hémostase, CHU Dijon, BP 77908,21079 Dijon cedex, France. Phone: 333802932 57; Fax: 333802934 24; E-mail: emmanuel.demaistre@chu-dijon.fr 
plications and it is therefore important to diagnose this adverse reaction as early as possible. The greater understanding of the pathogenesis of HIT, leading to the development of reliable laboratory tests, and the availability of new antithrombotic drugs (danaparoid, lepirudin, argatroban) explain why the management of HIT is easier today.

\section{I- Pathogenesis of HIT}

Heparin-induced thrombocytopenia is a very severe adverse drug reaction resulting from multicellular immune activation. ${ }^{1,2}$ Heparin-induced thrombocytopenia is an original model of drug-induced thrombocytopenia since it is rarely associated with bleeding manifestations. In contrast, arterial and venous thromboses are relatively frequent and explain the severity of HIT.

It is now accepted that HIT is due, in the majority of patients, to the development of $\mathrm{IgG}$ antibodies that activate platelets in the presence of heparin or highly sulfated polysaccharides (Figure 1). The epitopes which are recognized by HIT antibodies are expressed by macromolecular complexes composed of heparin and platelet factor 4 (PF4)..$^{3-6}$ The affinity of heparin and polysaccharides to PF4 is mainly dependent on their chain length and degree of sulfation. Platelet factor 4 also interacts with negatively charged glycosaminoglycans because it contains many basic positively charged amino acids such as lysine residues.

However, the formation of heparin/PF4 (H/PF4) immune complexes occurs mainly in the presence of stoichiometric concentrations of heparin and PF4. Therefore, when heparin is present at high concentrations, $\mathrm{H} / \mathrm{PF} 4$ complexes are dissociated in vitro.

Plasma PF4 concentrations may be high in specific clinical circumstances such as prosthetic hip surgery and cardiopulmonary bypass (CPB), due to in vivo platelet activation, and these situations are clearly at higher risk for HIT. ${ }^{7,8}$

Thrombocytopenia and thrombosis during HIT result from several mechanisms with an important in vivo role of platelet activation and markedly increased thrombin generation. $\mathrm{H} / \mathrm{PF} 4 / \mathrm{IgG}$ immune complexes bind to platelets via membrane $\mathrm{Fc}$ receptors, i.e., Fc $\gamma$ RIIa. ${ }^{9-11}$ Apart from inducing potent platelet activation, this interaction also contributes to the clearance of antibody-coated platelets by the reticuloendothelial system.

The pathogenic antibodies specific to modified PF4 are mainly IgGl, and sometimes IgG3. However, in some cases (less than $10 \%$ ) only $\operatorname{IgA}$ or $\operatorname{IgM}$ antibodies to PF4 are detectable. ${ }^{12}$ Such IgA or IgM antibodies are unable in vitro to activate platelets through

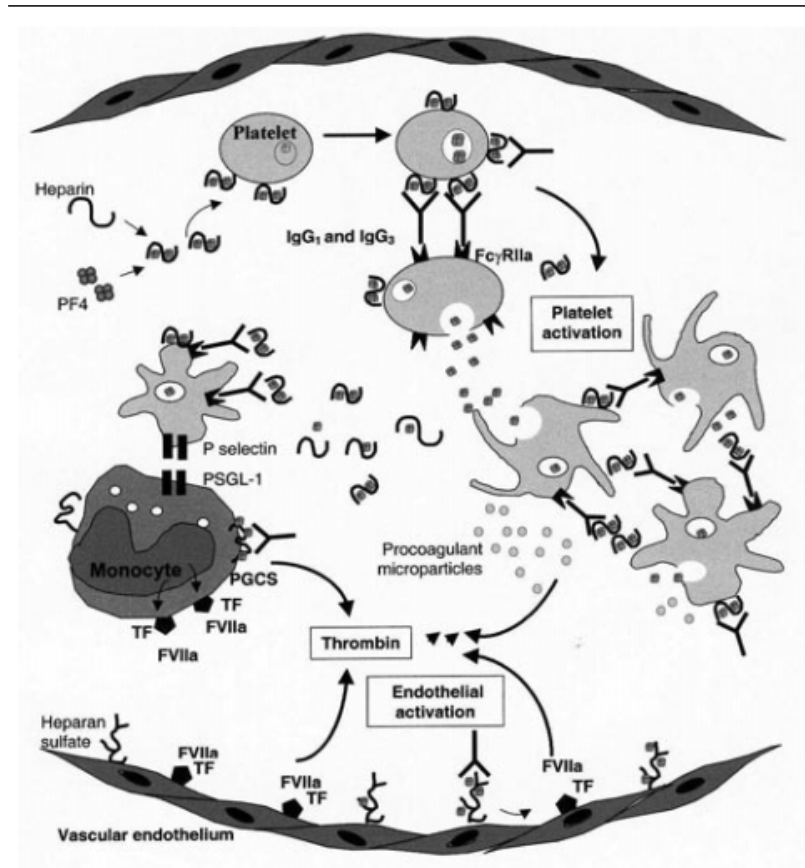

FIGURE 1 Pathogenesis of HIT. PF4 = platelet factor 4; PSGL-1 = P-selectin glycoprotein $1 ; \mathrm{CSPG}=$ chondroitin sulfate proteoglycan; $\mathrm{TF}=$ tissue factor.

FcyRIIA receptors in the presence of heparin, and therefore the mechanisms leading to HIT in affected patients are not fully understood.

On the other hand, HIT antibodies may be specific for proteins other than PF4, such as interleukin-8 or neutrophil activating peptide- $2 .{ }^{13}$ Therefore, such antibodies (IgA/M or anti-IL-8) may explain difficulties regarding the interpretation of biological assays in clinical practice, with discordant results between enzyme-linked immunosorbent assay (ELISA) and platelet activation tests. ${ }^{14}$

Venous and arterial thromboses are usually explained by the combined effects of platelet activation and increased thrombin generation, but might also be favoured by the anti-heparin activity of PF4. Platelets are stimulated powerfully in the presence of HIT antibodies and are not lysed as in other typical drug-induced thrombocytopenias. In contrast, activated platelets generate phospholipid microparticles during HIT, ${ }^{15}$ contributing to the development of a highly prothrombotic state. Heparin-induced thrombocytopenia heparin-dependent antibodies also bind to endothelial cells, ${ }^{16,17}$ leukocytes ${ }^{18}$ and monocytes ${ }^{19}$ and this interaction probably promotes the cellular synthesis and expression of tissue factor. This effect, that has been demonstrated by concordant in vitro 
studies, might also contribute to the development of thrombotic complications in patients with HIT, if they occur in vivo.

The pathogenic effects of HIT antibodies have, mainly, been documented by in vitro studies. However, further evidence that platelet activation, with subsequent thrombocytopenia induced by heparin-dependent antibodies to PF4, also occurs in vivo has recently been demonstrated using transgenic mice. ${ }^{20}$ This approach also emphasized the role of platelet Fc RIIA receptors in the pathogenesis of antibody-mediated thrombocytopenia and thrombosis.

FcyRIIA is polymorphic in both humans and mice, with either arginine or histidine at position 131 in its amino acid sequence. Several studies have evaluated the influence of this polymorphism on platelet activation induced by HIT antibodies and the development of the disease in humans, but no concordant results have been obtained. ${ }^{21}$ Fc $\gamma$ RIIIa receptors that are expressed on phagocytic cells may also be involved in HIT. ${ }^{22}$ FcgRIIIa is indeed polymorphic and the FcgRIIIa-158V allotype could increase the clearance of sensitized platelets and contribute to the development of thrombocytopenia. Finally, the risk of HIT is mainly dependent on the type of heparin administered (UFH > LMWH), on the underlying condition and on all circumstances inducing strong platelet activation favouring the formation of $\mathrm{H} / \mathrm{PF} 4$ complexes and the development of a pathogenic immune response.

Since UFH is now less frequently administered than LMWH in many countries, HIT is less frequently reported. However, as demonstrated recently, when it occurs in LMWH-treated patients, HIT is at least as severe as UFH-HIT. ${ }^{23}$

Since fondaparinux does not bind to PF4 in vitro, ${ }^{6}$ and since HIT antibodies do not react with pentasaccharide/PF4 complexes, ${ }^{24,25}$ it is expected that this type of immune thrombocytopenia will not occur during treatment with this novel synthetic antithrombotic agent. However, this has yet to be confirmed and platelet monitoring remains essential with this anticoagulant, as with LMWH.

\section{II- Diagnosis of HIT}

Heparin-induced thrombocytopenia is often difficult to diagnose because many patients treated with heparin have other diseases or have received drugs other than heparin that are also potential causes of thrombocytopenia. ${ }^{26,27}$ Correction of the platelet count after discontinuation of heparin therapy is very suggestive of HIT but is not sufficient to confirm the diagnosis. Thus, the diagnosis of HIT should rely both on clinical criteria, mainly thrombocytopenia with or without thrombosis, and laboratory criteria based on assays that detect heparin-dependent antibodies.

\section{II-I Clinical criteria for HIT}

Thrombocytopenia is the central feature of HIT. Thus, platelet count monitoring during heparin treatment is mandatory in every patient receiving UFH or LMWH. ${ }^{28}$ Heparin-induced thrombocytopenia should be suspected when thrombocytopenia (i.e., a platelet count below $150 \times 10^{9} \mathrm{~L}^{-1}$ ) occurs during heparin treatment. A substantial fall of more than $40 \%$ below the baseline count can also suggest HIT, even if the platelet count nadir remains above 150 $\times 10^{9} \mathrm{~L}^{-1}$. Ethylenediaminetetraacetic acid (EDTA) is used to anticoagulate blood samples and EDTAinduced pseudothrombocytopenia should be excluded by verifying the platelet count when another anticoagulant is used. ${ }^{29}$

Typically, the fall in platelet count occurs between the fifth and 20th day after initiation of heparin. However, in some patients a more rapid fall in the platelet count can occur because of recent heparin use, generally within the past three months. ${ }^{30}$ Consequently, analysis of the platelet count time course must take into account previous exposure to heparin (UFH or LMWH). Thrombocytopenia is often moderate (platelet count nadir about $55 \times$ $\left.10^{9} \mathrm{~L}^{-1}\right),{ }^{1}$ but severe thrombocytopenia can occur in a minority of patients, particularly when HIT is associated with disseminated intravascular coagulation (DIC).

Thrombosis rather than bleeding predominates whatever the severity of thrombocytopenia. ${ }^{31}$ Arterial thrombosis was first described during HIT but venous thrombosis (proximal deep venous thrombosis or pulmonary embolism) is more frequent and is observed in about $50 \%$ of patients. ${ }^{3-33}$ The localization of thrombi is influenced by the clinical setting: venous thromboses are observed mainly in surgical patients, and arterial thromboses in cardiovascular patients. The occurrence of thrombosis is unpredictable and can be observed during the fall in platelet count, at the nadir, at the early platelet recovery stage or several days after discontinuation of heparin. ${ }^{1}$ Some clinical features are characteristic of HIT, i.e., extensive or bilateral deep venous thrombosis, upper limb thrombosis at the site of a central venous catheter, thrombosis of the adrenal veins leading to hemorrhagic infarction, and thrombosis of the distal aorta or the large arteries of the lower limbs. ${ }^{34}$ In view of the high risk of thrombosis, the meticulous search for a new thrombosis or extension of pre-existing thromboses are advised in all patients with suspected HIT. ${ }^{35,36}$ 
Acute systemic reactions or transient amnesia have been described following the iv administration of a bolus of heparin. ${ }^{1}$ Skin lesions (erythema or necrosis) at heparin injection sites are also possible features of HIT. In addition, skin lesions have been reported in patients with detectable HIT antibodies but no thrombocytopenia. ${ }^{37}$ About $10 \%$ of HIT patients have DIC and, therefore, this does not exclude the diagnosis of HIT. Venous limb gangrene has been reported in HIT patients treated by oral anticoagulants with a high international normalized ratio (INR) of the prothrombin time (PT) and this appears to result from a profound disturbance of the procoagulant-anticoagulant balance. ${ }^{38}$

Analysis of the time profile of the platelet count is sometimes difficult because a $30 \%$ decrease is frequently observed after orthopedic or cardiovascular surgery with $\mathrm{CPB}$. In these situations, thrombocytopenia during the first four postoperative days is rarely attributable to HIT. ${ }^{39,40}$ A biphasic pattern of the platelet count with an initial fall immediately after $\mathrm{CPB}$, followed by a rise within six days and then by a further fall is suggestive of HIT and should always require screening for HIT antibodies. ${ }^{41,42}$

When the time course of the platelet count is compatible with HIT and/or when new thrombotic complications occur, heparin should be stopped immediately and replaced by another anticoagulant (see below). The diagnosis will be established retrospectively after discontinuation of heparin (which, if successful, leads to correction of the platelet count) and after laboratory testing to demonstrate the presence of heparin-dependent antibodies in the patient's plasma.

\section{II-2 Laboratory criteria for HIT}

Two methods are available currently to detect heparin-dependent antibodies, ${ }^{43}$ i.e., platelet activation tests and antigen assays.

Platelet activation tests are all based on the detection of donor platelet activation in the presence of the patient's plasma and heparin. The test is positive if the patient's plasma induces maximal activation in the presence of 0.1 to $0.5 \mathrm{IU} \cdot \mathrm{mL}^{-1}$ heparin with no activation at 0 and 10 (or more) IU. $\mathrm{mL}^{-1}$. Inhibition by an $\mathrm{Fc}$ receptor-blocking monoclonal antibody increases the specificity of the test. Platelet aggregometry performed with citrated platelet-rich plasma is the test most commonly used to detect platelet-activating HIT antibodies. However this method is difficult to standardize and its sensitivity varies widely from one laboratory to another (35-85\%). ${ }^{14,44-46}$ Greater sensitivity and specificity are achieved using washed plate- lets. Platelet activation can be assessed by a variety of methods, including release of radioactive serotonin (the method used most frequently and considered the "gold standard"), ${ }^{47}$ visual assessment of platelet aggregation performed in microtitre wells, ${ }^{48}$ flow cytometry to assess platelet-derived microparticles or binding of annexin V. ${ }^{15,49}$ Unfortunately, these assays with washed platelets are technically demanding and can only be performed in reference laboratories.

Moreover, donor selection is important as platelet responsiveness to heparin-dependent antibodies varies in normal donors. ${ }^{45,50}$ Performing the test with platelets from several different donors is highly recommended to enhance sensitivity, particularly when platelet aggregation tests are performed with plateletrich plasma.

Antigen assays detect the binding of antibodies to $\mathrm{H} / \mathrm{PF} 4$ complexes by incubating serum or patient plasma in wells covalently coated with PF4 bound either to heparin (Asserachrom HPIA ${ }^{\circledR}$ Stago, Asnieres, France $)^{3}$ or polyvinyl sulphonate (GTIHAT $^{\circledR}$, Brookfield, WI, USA). ${ }^{51}$ These assays are easy to perform, well standardized and the upper limit is usually set at the mean +3 SD obtained using normal sera. They exhibit good sensitivity (>90\%), with excellent negative predictive value for HIT. ${ }^{14}$ However, HIT antibodies can be directed against antigens other than PF4 (IL-8 and NAP-2) but this situation is rather infrequent $\left(<10 \%\right.$ of HIT patients). ${ }^{13,52,53}$ The main inconvenience of these antigen assays results from their high sensitivity to detecting anti-H/PF4 antibodies not always associated with clinical HIT, and this is particularly frequent after cardiac surgery with $\mathrm{CPB} .7,54,55$ Therefore, detection of anti-H/PF4 antibodies by ELISA does not confirm HIT and the combination of platelet activation tests and antigen assays is mandatory to provide the diagnosis in such circumstances. ${ }^{14}$ A simple test based on the ID-microtyping particle agglutination system has been described recently for the rapid detection of anti-H/PF4 antibodies, ${ }^{56}$ but further evaluations are necessary.

\section{II-3 Practical recommendations for the diagnosis of HIT}

Early detection of HIT is essential in view of the potential severity of thrombotic complications and, since thrombocytopenia is the most common feature of HIT, platelet count monitoring is mandatory before (baseline platelet count) and during heparin treatment. However, in the seventh American College of Chest Physicians consensus conference, ${ }^{28}$ the frequency of monitoring will depend on the clinical situation (with the suggestion to not monitor plate- 
TABLE I Estimating the pretest probability of heparin-induced thrombocytopenia: the "four T"s ${ }^{1}$

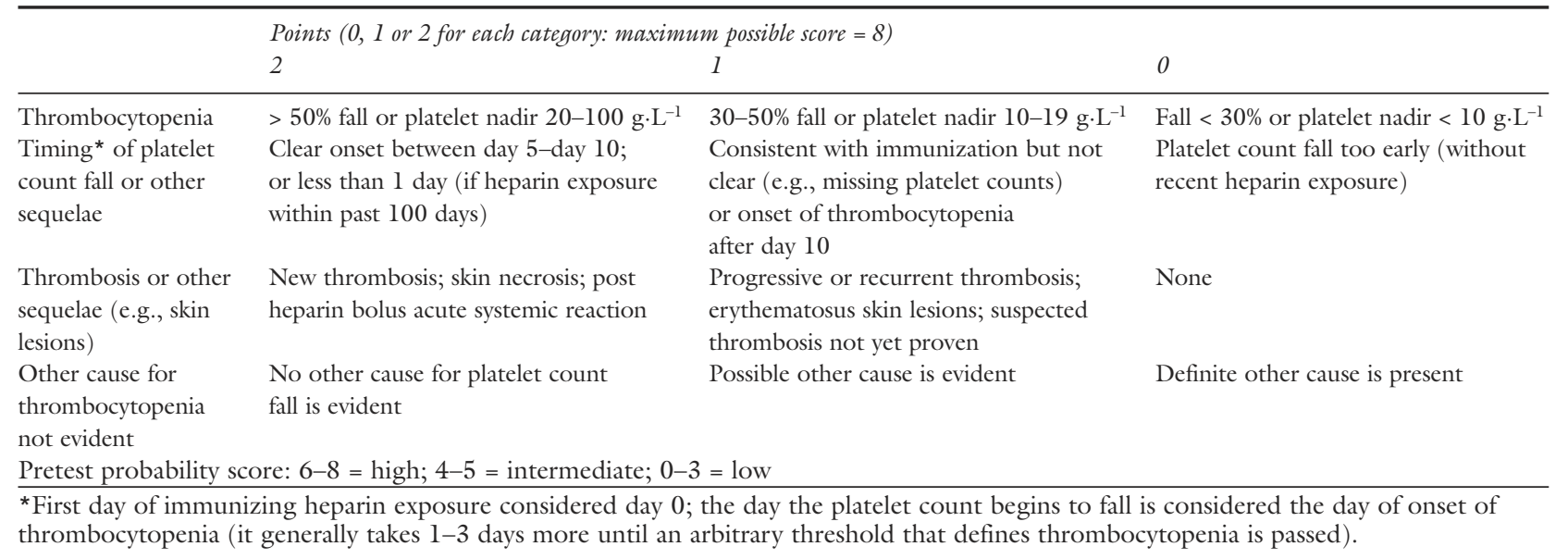

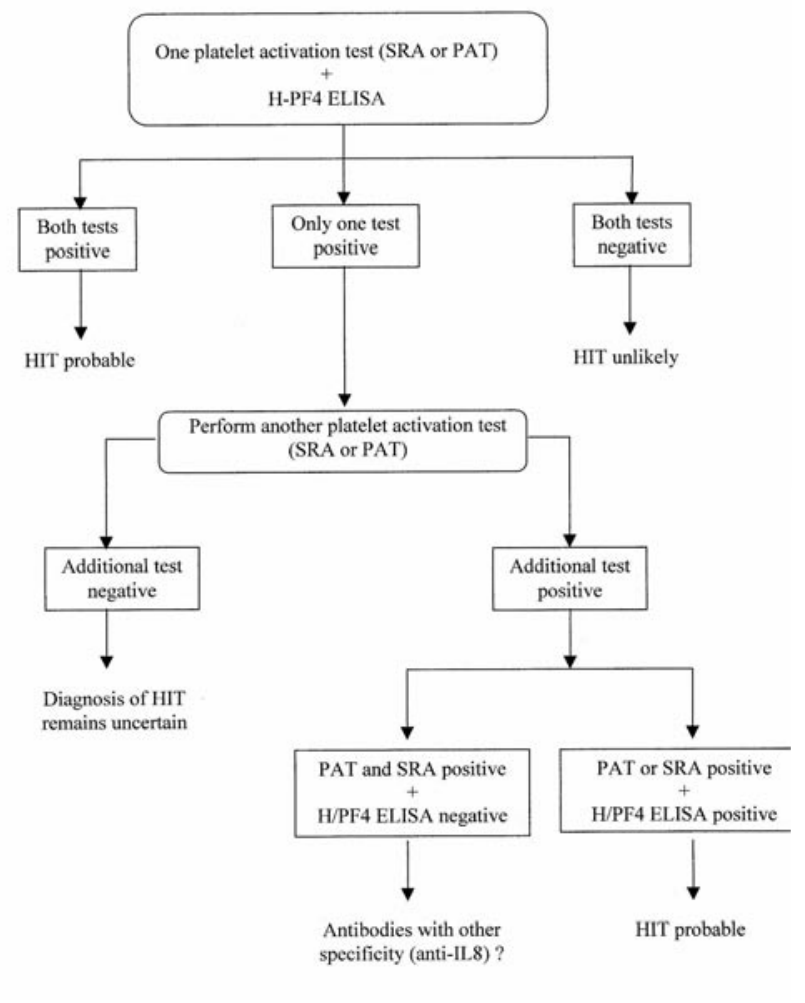

FIGURE 2 Flow chart used to interpret results of platelet aggregation test (PAT), heparin-platelet factor enzyme-linked immunosorbent assay ( $\mathrm{H} / \mathrm{PF} 4 \mathrm{ELISA})$ and $14 \mathrm{C}$-serotonin release assay (SRA) for diagnosis of heparininduced thrombocytopenia (HIT). let count routinely in medical or obstetrical patients receiving prophylactic doses of $\mathrm{LMWH}$ ).

Alternative anticoagulant treatments can be more difficult to manage than heparin (see below). It is therefore necessary to evaluate carefully the likelihood of HIT before deciding to withdraw heparin. Warkentin and Heddle proposed a pre-test probability of HIT based on four criteria: (i) thrombocytopenia (ii) timing of fall in platelet count (iii) thrombosis or other sequelae and (iv) other potential causes of thrombocytopenia (Table I). ${ }^{57} \mathrm{~A}$ diagnostic score for HIT after $\mathrm{CPB}$ was also proposed recently. ${ }^{41}$

Laboratory investigations including the PT, activated partial thromboplastin time (aPTT), measurement of fibrinogen and D-dimers or levels of fibrinogen degradation products should be performed to investigate DIC. Platelet monitoring should also be maintained after heparin withdrawal, since a rise in platelet count within five days after heparin discontinuation is essential for the retrospective diagnosis of HIT.

Blood sampling for the detection of HIT antibodies should be performed after heparin withdrawal (four or $12 \mathrm{hr}$ after cessation of UFH or LMWH, respectively) in order to allow the interpretation of platelet activation assays. Heparin-induced thrombocytopenia antibodies are detectable for up to four to six weeks after heparin withdrawal, but plasma should be collected as soon as possible because the antibody concentration can decrease rapidly. A combination of two categories of tests is recommended in order to optimize the sensitivity and the specificity of the laboratory diagnosis. ${ }^{14}$ If both tests are negative, the diagnosis of HIT can generally be ruled out (negative predictive value close to $100 \%$ ) and should lead to further investigations into other causes of thrombocytopenia. ${ }^{27}$ If both acti- 
vation and antigen assays are positive, the diagnosis of HIT is very likely. Discordant results between antigen and platelet activation assays can be obtained and are difficult to interpret. Positive platelet activation with a negative antigen assay is rare and can be due to antiNAP-2 or anti-IL-8 antibodies. ${ }^{13,52}$ A positive ELISA result with a negative activation test has to be interpreted according to the patient's clinical situation. Indeed, the poor specificity of antigen assays for HIT after cardiac surgery explains that a positive result does not necessarily prove HIT. In some patients, $\operatorname{IgM}$ and IgA specific to PF4 are the only antibodies detectable by ELISA, but the possibility that these subclasses might activate platelets and cause HIT remains a matter of debate. ${ }^{1,52} \mathrm{~A}$ flowchart taking into account these difficulties, which can be used to interpret the results of platelet activation and antigen assays, has therefore been proposed by Pouplard et al. (Figure 2). ${ }^{14}$

Lastly, a clear conclusion should be written for all patients in whom HIT has been suspected and added to the medical record to ensure appropriate management when further anticoagulation is required.

\section{Treatment of HIT}

When there are enough clinical arguments to suspect HIT, the first action is to discontinue heparin and contact a specialized centre for laboratory investigations (see below).

Alternative anticoagulant treatment must then be considered, without waiting for laboratory confirmation. Tests (antigen assays and platelet activation tests) are performed in specialized centers and often require several days to complete. Heparin withdrawal alone is insufficient to control the underlying prothrombotic state related to HIT which persists for several days. According to Warkentin et al., about $50 \%$ of patients will have thrombotic complications within 30 days after withdrawal of heparin if no replacement treatment is administered. ${ }^{33}$

\section{III-I Alternative anticoagulant treatment (Tables II and III)}

Before initiating alternative anticoagulant treatment, all potential sources of heparin must be removed (heparin flushes in the catheters, heparinized catheters, etc.).

The use of LMWH is not advisable, because of the high risk of cross reactivity. Antiplatelet agents such as acetyl salicylic acid and clopidogrel are usually ineffective in controlling the thrombin generation triggered by platelet activation. Oral anticoagulants are not recommended in the acute phase, until the thrombocytopenia has resolved and effective anticoagula- tion is initiated with the alternative treatment. Other treatments have been reported (iv gammaglobulins, plasma exchange) and must be considered as adjuncts to the replacement drugs discussed below in lifethreatening states.

To make a choice between replacement drugs, their availability (which varies by country) must be considered, along with the clinical features of HIT (venous/ arterial thrombosis; prophylactic/therapeutic regimen), the patient's status (renal and hepatic function), and the experience of the centre. ${ }^{1,58-60}$

- Danaparoid (Orgaran ${ }^{\circledR}$, Organon, Oss, The Netherlands) has been approved in Europe and Canada for approximately ten years. Its principal advantage is the large, published experience with this drug. Its biggest drawback is its chemical composition, i.e., a mixture of glycosaminoglycans derived from porcine gut mucosa, close to heparin fragments (heparan sulfate, dermatan sulfate and chondroitin sulfate), with the possibility of cross-reactivity with HIT antibodies. The anticoagulant activity of danaparoid is dependent on the presence of antithrombin (like heparin) and is mainly related to its ability to inhibit factor Xa (anti$\mathrm{Xa}$ /anti-IIa ratio $>20$ ). Danaparoid is available only for $i v$ and $s c$ administration and its bioavailability after $s c$ injection is almost $100 \%$. The half-life for anti-Xa activity is $24 \mathrm{hr}$ and for antithrombin generation is seven hours, explaining the dosage schedule for the $s c$ administration of danaparoid (two or three times daily). Overdose can occur rapidly in case of renal impairment.

- Lepirudin (Refludan ${ }^{\circledR}$, Berlex Montville NJ, USA and Pharmion, Cambridge, UK) has been available in the USA and Europe for several years. Natural hirudin is extracted from the salivary glands of the medicinal leech Hirudo medicinalis, while lepirudin is produced by recombinant technology. One of the main advantages of lepirudin is the absence of cross-reactivity with HIT antibodies since it is a short peptide (65 amino acids) that does not interact with PF4. Lepirudin has a short half-life and does not require a plasma cofactor to exert its antithrombotic action. Its biggest drawbacks are the need for strict laboratory monitoring and the risk of bleeding, documented in preliminary studies in cardiovascular fields. Moreover, patients should be informed that they have received lepirudin since fatal anaphylactic reactions have been reported in patients re-exposed to this drug. ${ }^{61}$ Lepirudin is a direct, specific and irreversible inhibitor of thrombin, whether or not thrombin is bound to a fibrin clot. Lepirudin is only administered intravenously. As for danaparoid, lepirudin elimination is impaired in patients with renal dysfunction, even when renal impairment is moderate. 
TABLE II Alternative anticoagulant treatment (adapted from Alving) ${ }^{58}$

\begin{tabular}{|c|c|c|c|}
\hline & Danaparoid $=$ Orgaran ${ }^{\circledR}$ & Lepirudin $=$ Refludan ${ }^{\circledR}$ & Argatroban = Argatroban $®$ \\
\hline Chemistry & $\begin{array}{l}\text { Glycosaminoglycans (heparan-, } \\
\text { dermatan- and chondroitin sulphate) }\end{array}$ & Recombinant protein & Synthetic arginine analogue \\
\hline Anticoagulant effect & $\begin{array}{l}\text { anti-Xa/anti-IIa ratio }>20 \\
\text { antithrombin dependent }\end{array}$ & $\begin{array}{l}\text { - anti-IIa (free and clot-bound) } \\
\text { - irreversible effect }\end{array}$ & $\begin{array}{l}\text { - anti-IIa (free and clot-bound) } \\
\text { - reversible effect }\end{array}$ \\
\hline Half-life & $\begin{array}{l}24 \mathrm{hr} \text { for anti-Xa activity ; } 7 \mathrm{hr} \text { for } \\
\text { thrombin generation }\end{array}$ & 1 to $2 \mathrm{hr}$ & $40 \mathrm{~min}$ \\
\hline Excretion & Renal & Renal & Liver \\
\hline Antidote & None & None & None \\
\hline Monitoring & $\begin{array}{l}\text { Anti-Xa activity (specific } \\
\text { for danaparoid) }\end{array}$ & $\begin{array}{l}\text { aPTT } \\
\text { (ECT, thrombin-based } \\
\text { chromogenic assay) }\end{array}$ & PTT \\
\hline Reversal & Protamine sulphate? & Hemofiltration & $?$ \\
\hline Regimen & $\begin{array}{l}\text { Prophylactic } \\
\text { Therapeutic } \\
\text { CPB }\end{array}$ & $\begin{array}{l}\text { Therapeutic } \\
\text { CPB }\end{array}$ & Therapeutic \\
\hline Immune effects & $\begin{array}{l}\text { Cross reactivity with anti- } \\
\mathrm{H} / \mathrm{PF} 4 \text { antibodies }\end{array}$ & $\begin{array}{l}\text { Antibodies to lepirudin } \\
\text { (recombinant product) }\end{array}$ & None \\
\hline
\end{tabular}

$\mathrm{aPTT}=$ activated partial thromboplastin time; $\mathrm{ECT}=$ ecarin clotting time; $\mathrm{CPB}=$ cardiopulmonary bypass.

TABLE III Regimens for alternative treatments (adapted from Warkentin) ${ }^{1}$

\begin{tabular}{|c|c|c|c|}
\hline Anticoagulant & Prophylactic regimen & Therapeutic regimen & Comment \\
\hline $\begin{array}{l}\text { Danaparoid } \\
=\text { Orgaran }{ }^{\circledR}\end{array}$ & $\begin{array}{l}\text { No bolus } 750 \mathrm{U} \times 3 \mathrm{sc} \\
(1250 \mathrm{U} \times 3 \text { if body weight } \\
>90 \mathrm{~kg})\end{array}$ & $\begin{array}{l}\text { Bolus }{ }^{*} 2250 \mathrm{U} \text {, Then } i v \text { infusion } \\
400 \mathrm{U} \cdot \mathrm{hr}^{-1} \times 4 \mathrm{hr} \text {, then } \\
300 \mathrm{U} \cdot \mathrm{hr}^{-1} \times 4 \mathrm{hr} \text {, then } 150-200 \mathrm{U} \cdot \mathrm{hr}^{-1} \\
\text { monitoring by anti-Xa activity } \\
\left(0.5 \text { to } 0.8 \mathrm{U} \text { anti-Xa } \cdot \mathrm{mL}^{-1}\right)\end{array}$ & $\begin{array}{l}\text { - risk of cross reactivity } \\
\text { - *adjust bolus for body weight } \\
(<60 \mathrm{~kg}=1500 \mathrm{U} \\
75-90 \mathrm{~kg}=3000 \mathrm{U} \\
>90 \mathrm{~kg}=3750 \mathrm{U})\end{array}$ \\
\hline $\begin{array}{l}\text { Lepirudin } \\
=\text { Refludan }{ }^{\circledR}\end{array}$ & Not approved & $\begin{array}{l}\text { Bolus }^{* *} 0.4 \mathrm{mg} \cdot \mathrm{kg}^{-1} \\
\text { Then } i v \text { infusion }{ }^{*} 0.15 \mathrm{mg} \cdot \mathrm{kg}^{-1} \\
\text { per hour, monitoring by aPTT } \\
\left(1.5 \text { to } 2.5 \text { times baseline }{ }^{* *} \text { ) }\right.\end{array}$ & $\begin{array}{l}\text { - risk of anaphylactic shock after } \\
\text { bolus (specially if reexposure) } \\
{ }^{* *} \text { risk of early overdose } \\
\text { in discussion: bolus limited to } \\
\text { life-threatening thrombosis, } \\
\text { reduction of the } i v \text { infusion to } \\
0.1 \mathrm{mg} \cdot \mathrm{kg}^{-1} \text { per hour, aPTT } \\
\text { range } 1.5 \text { to } 2 \text { times baseline }\end{array}$ \\
\hline $\begin{array}{l}\text { Argatroban } \\
=\text { Argatroban }{ }^{\circledR}\end{array}$ & $\begin{array}{l}\text { No bolus } \\
\text { iv infusion } 2 \mu \mathrm{g} \cdot \mathrm{kg}^{-1} \cdot \mathrm{min}^{-1} \text {, } \\
\text { monitoring by APTT } \\
\text { ( } 1.5 \text { to } 3 \text { times baseline) }\end{array}$ & - same dosage & $\begin{array}{l}\text { - limited experience } \\
\text { - reversible antithrombotic effect }\end{array}$ \\
\hline
\end{tabular}

$\mathrm{aPTT}=$ activated partial thromboplastin time.

The half-life is short (one to two hours), but increases rapidly with the deterioration of renal function (up to $52 \mathrm{hr}$ ).

- Argatroban (Argatroban ${ }^{\circledR}$, GlaxoSmithKline, Houston TX, USA) is available only in North America and in Japan. This synthetic drug binds reversibly to the catalytic site of thrombin and has a very low molecular weight $(547 \mathrm{Da})$ allowing it to inhibit thrombin binding to fibrin clots. Its short half-life (40-50 $\mathrm{min})$ and its hepatobiliary excretion are two major advantages in critically ill patients. It is the drug of choice in cases of renal insufficiency. ${ }^{62,63}$
No randomized trial has compared these drugs. In a retrospective study, Farner et al. compared the outcomes of HIT patients treated with lepirudin or danaparoid during the same period. ${ }^{64}$ Similar outcomes were observed in patients treated with the therapeutic regimen but, with the prophylactic regimen, patients receiving danaparoid had a higher risk of thromboembolic events. Failure of danaparoid was not observed by others. ${ }^{65}$ Farner's results can be explained by the use of a prophylactic regimen of danaparoid ${ }^{58}$ (no prior bolus when steady state anti-Xa activity is reached after five half-lives, i.e., five days), while the 
lepirudin prophylactic regimen was, in fact, close to the latest recommendations for the therapeutic regimen. Indeed, to avoid overdosage in the therapeutic regimen, Greinacher recently recommended to avoid the initial bolus in patients without life-threatening thrombosis and to begin the infusion rate at 0.1 $\mathrm{mg} \cdot \mathrm{kg}^{-1} \cdot \mathrm{hr}^{-1}$ (i.e., the prophylactic regimen), with a lower target aPTT, ranging between 1.5 to two times baseline. ${ }^{28}$ The level of anticoagulation in asymptomatic HIT patients must be considered in view of the high thrombotic risk. Tardy et al. recommended systematic screening for subclinical deep venous thrombosis by duplex ultrasonography to define treatment intensity. ${ }^{35}$ Some authors consider that therapeutic doses should be recommended to manage HIT, even when prevention of thrombosis is the aim. ${ }^{1}$ With argatroban, only one regimen is proposed for HIT patients (Table III).

Replacement treatment over a long period should be avoided because of the risk of cross-reactivity (danaparoid), the absence of antidote (danaparoid and lepirudin), the need for careful monitoring with the risk of accumulation, and the absence of validation in several situations. Switching to an oral anticoagulant must begin when the platelet count has recovered, with an overlap (as with heparin), but reducing the dose of the replacement treatment $(750 \mathrm{U} \times 3 s c$ for danaparoid; target aPTT $\times 1.5$ normal for lepirudin). Direct thrombin inhibitors (lepirudin, argatroban) prolong the PT and co-administration of these drugs with an oral anticoagulant produces a combined effect on the INR. Measurement of vitamin K-dependent factors after dilution of test plasma can help management.

\section{III-2 Laboratory monitoring of treatment}

Monitoring must be appropriate for the drug. $1,58,59$

- Monitoring for danaparoid is based on anti-Xa activity with specific calibration (commercial or local plasma spiked with danaparoid in vitro). This test is not readily available (prior contact with the referring hematologist is needed). Such monitoring is recommended in cases of therapeutic dosage (therapeutic target $=0.5-0.8 \mathrm{U}$ anti-Xa. $\mathrm{mL}^{-1}$ ) and/or renal insufficiency. Cross-reactivity with danaparoid can be suspected in vitro with functional tests, but the best way is to monitor the platelet count during danaparoid treatment. If partial recovery is not observed during the first two or three days of danaparoid treatment, cross reactivity or a diagnosis other than HIT should be considered.

- Monitoring is required for both the prophylactic and therapeutic lepirudin regimens. The test recom- mended in the literature and in the product description is the aPTT. In contrast to heparin, the response is not linear in the therapeutic range, and overdose can be difficult to detect early. Heightened vigilance is necessary in cases of renal insufficiency, even moderate. The therapeutic range is narrow and laboratory monitoring must be improved. Many centres have used other tests with a linear response: e.g., the ecarin clotting time (ECT), an anti-thrombin chromogenic test and a modified thrombin test. Generation of antibodies against lepirudin have been reported in approximately $40 \%$ of treated patients. ${ }^{66,67}$ Although antihirudin antibodies usually have no clinical significance, the aPTT can sometimes increase without changing the dose, probably due to antibody/hirudin complexes that are poorly cleared by the kidneys.

- The aPTT is recommended to monitor argatroban and the therapeutic range is wide ( 1.5 to three times baseline). Little experience is available for this new drug in this setting. As expected, no immune effect has been reported.

\section{III-3 Miscellaneous considerations}

To avoid overdosing, renal function (danaparoid, lepirudin), hepatic function (argatroban) and half-life must be taken into account, because no true antidote is available for these drugs. Protamine sulfate has been proposed for danaparoid but its efficacy is hypothetical because protamine would neutralize only the antithrombin (anti-IIa) activity of danaparoid. Recently, the therapeutic dosage of lepirudin has been questioned: a bolus should be reserved to situations where the risk of thrombosis is very high, the initial infusion rate should be reduced to $0.1 \mathrm{mg} \cdot \mathrm{kg}^{-1} \cdot \mathrm{hr}^{-1}$, and the aPTT maintained within a narrow window $(1.5 \times$ to two times that of normal plasma). ${ }^{1}$

In cases of bleeding, hemofiltration is recommended for lepirudin, provided that appropriate filters are chosen (high-flux polysulfone dialyzers). Otherwise, the infusion of plasma can be helpful. Neither desmopressin nor factor concentrates are effective; recombinant activated factor VII (Novoseven ${ }^{\circledR}$, Novo Nordisk, Bagsvaerd, Danmark) is contra-indicated in this prothrombotic state. The transfusion of platelet concentrate can potentiate the HIT process in the acute phase by providing fresh platelets for the activating antibodies.

Patients with renal impairment are cautioned against taking danaparoid and lepirudin, and caution is advised also for those with liver impairment taking argatroban. A protocol is available for danaparoid during chronic hemofiltration, ${ }^{68}$ and recommendations have been proposed for lepirudin. ${ }^{69}$ In pregnant and 
lactating women, danaparoid should be used whereas lepirudin and argatroban are contraindicated. Some case-reports on the use of danaparoid in pediatrics have been published and a regimen has been proposed (bolus $30 \mathrm{U} \cdot \mathrm{kg}^{-1}$ followed by an infusion of 1.2 to 2 $\left.\mathrm{U} \cdot \mathrm{kg}^{-1}\right) .^{70}$

Lepirudin is preferred for CPB. Lepirudin monitoring must be performed in the operating room with the ECT in whole blood. ${ }^{71-73}$ In cases of bleeding or accumulation at the end of $\mathrm{CPB}$, hemofiltration through an appropriate membrane can provide rapid elimination of the product. ${ }^{74}$ Regimens has been proposed for danaparoid, but its long half-life and the absence of an antidote severely limit its use. ${ }^{75}$ Heparin can be administered at the time of surgery if HIT is older than three months, and laboratory tests are negative. In an emergency situation, in the absence of previous experience with lepirudin, another option is to combine heparin with iloprost ${ }^{76}$ or tirofiban, an antiglycoprotein IIb/IIIa, but bleeding complications have been reported with the latter. ${ }^{77}$

No alternative treatment regimen has been reported for surgery other than CPB. Lepirudin or argatroban may be easier to use in view of their short half-lives.

In summary, HIT is a well-known adverse event associated with heparin. It is a severe condition that may result in catastrophic thrombotic complications or death. However the diagnosis remains difficult in spite of the development of laboratory tests. Management is easier with new drugs such as danaparoid, lepirudin and argatroban, but alternative treatments remain difficult to manage. Close contact between clinicians and hematologists is essential to optimize the diagnosis and treatment of HIT.

\section{Acknowledgements}

We thank Claire Pouplard for her valuable help in preparing this manuscript and Ms. Doreen Raine for editing the English.

\section{References}

1 Warkentin TE. Heparin-induced thrombocytopenia: pathogenesis and management. Br J Haematol 2003; 121: 535-55.

2 Gruel Y, Pouplard C. Physiopathologie des thrombopénies et des thromboses induites par l'héparine. Hématologie 2002; 8: 241-52.

3 Amiral J, Bridey F, Dreyfus $M$, et al. Platelet factor 4 complexed to heparin is the target for antibodies generated in heparin-induced thrombocytopenia. Thromb Haemost 1992; 68: 95-6.

4 Greinacher A, Michels I, Mueller-Eckhardt C. Heparinassociated thrombocytopenia: the antibody is not hepa- rin specific. Thromb Haemost 1992; 67: 545-9.

5 Kelton JG, Smith JW, Warkentin TE, Hayward CP, Denomme GA, Horsewood P. Immunoglobulin G from patients with heparin-induced thrombocytopenia binds to a complex of heparin and platelet factor 4 . Blood 1994; 83: 3232-9.

6 Ranova L, Poncz M, McKenzie SE, et al. Ultralarge complexes of PF4 and heparin are central to the pathogenesis of heparin-induced thrombocytopenia. Blood 2005; 105: 131-8.

7 Pouplard C, May MA, Iochmann S, et al. Antibodies to platelet factor 4-heparin after cardiopulmonary bypass in patients anticoagulated with unfractionated heparin or a low-molecular-weight heparin : clinical implications for heparin-induced thrombocytopenia. Circulation 1999; 99: 2530-6.

8 Warkentin TE, Sheppard JA, Horsewood P, Simpson PJ, Moore JC, Kelton JG. Impact of the patient population on the risk for heparin-induced thrombocytopenia. Blood 2000; 96: 1703-8.

9 Brandt JT, Isenhart CE, Osborne JM, Abmed A, Anderson CL. On the role of platelet Fc gamma RIIa phenotype in heparin-induced thrombocytopenia. Thromb Haemost 1995; 74: 1564-72.

10 Carlsson LE, Santoso S, Baurichter G, et al. Heparininduced thrombocytopenia: new insights into the impact of the FcgammaRIIa-R-H131 polymorphism. Blood 1998; 92: 1526-31.

11 Arepally G, McKenzie SE, Jiang XM, Poncz M, Cines $D B$. Fc gamma RIIA H/R 131 polymorphism, subclass-specific IgG anti-heparin/platelet factor 4 antibodies and clinical course in patients with heparininduced thrombocytopenia and thrombosis. Blood 1997; 89: 370-5.

12 Amiral J, Wolf M, Fischer A, Boyer-Neumann C, Vissac $A$, Meyer D. Pathogenicity of IgA and/or IgM antibodies to heparin-PF4 complexes in patients with heparin-induced thrombocytopenia. Br J Haematol 1996; 92: 954-9.

13 Amiral J, Marfaing-Koka A, Wolf M, et al. Presence of autoantibodies to interleukin- 8 or neutrophil-activating peptide- 2 in patients with heparin-associated thrombocytopenia. Blood 1996; 88: 410-6.

14 Pouplard C, Amiral J, Borg JY, Laporte-Simitsidis S, Delahousse B, Gruel $\Upsilon$. Decision analysis for use of platelet aggregation test, carbon 14-serotonin release assay, and heparin-platelet factor 4 enzyme-linked immunosorbent assay for diagnosis of heparin-induced thrombocytopenia. Am J Clin Pathol 1999; 111: 700-6.

15 Lee DH, Warkentin TE, Denomme GA, Hayward CP, Kelton JG. A diagnostic test for heparin-induced thrombocytopenia: detection of platelet microparticles using flow cytometry. Br J Haematol 1996; 95: 724-31. 
16 Cines DB, Tomaski A, Tannenbaum S. Immune endothelial-cell injury in heparin-associated thrombocytopenia. N Engl J Med 1987; 316: 581-9.

17 Visentin GP, Ford SE, Scott JP, Aster RH. Antibodies from patients with heparin-induced thrombocytope$\mathrm{nia} /$ thrombosis are specific for platelet factor $4 \mathrm{com}$ plexed with heparin or bound to endothelial cells. J Clin Invest 1994; 93: 81-8.

18 Khairy M, Lasne D, Brohard-Bobn B, Aiach M, Rendu $F$, Bachelot-Loza C. A new approach in the study of the molecular and cellular events implicated in heparin-induced thrombocytopenia. Formation of leukocyte-platelet aggregates. Thromb Haemost 2001; 85: 1090-6.

19 Pouplard C, Iochmann S, Renard B, et al. Induction of monocyte tissue factor expression by antibodies to heparin-platelet factor 4 complexes developed in heparininduced thrombocytopenia. Blood 2001; 97: 3300-2.

20 Reilly MP, Taylor SM, Hartman NK, et al. Heparininduced thrombocytopenia/thrombosis in a transgenic mouse model requires human platelet factor 4 and platelet activation through FcgammaRIIA. Blood 2001; 98: 2442-7.

21 Denomme G. The platelet Fc receptor in heparininduced thrombocytopenia. In: Greinacher A (Ed.). Heparin-Induced Thrombocytopenia, $2^{\text {nd }}$ ed. NewYork-Basel: Marce Dekker, Inc; 2001: 189-214.

22 Gruel $\Upsilon$, Pouplard C, Lasne D, Magdelaine-Beuzelin $C$, Charroing $C$, Watier $H$. The homozygous FcgammaRIIIa-158V genotype is a risk factor for heparin-induced thrombocytopenia in patients with antibodies to heparin-platelet factor 4 complexes. Blood 2004; 104: 2791-3.

23 Gruel Y, Pouplard C, Nguyen P, et al; French HeparinInduced Thrombocytopenia Study Group. Biological and clinical features of low-molecular-weight heparininduced thrombocytopenia. Br J Haematol 2003; 121 : 786-92.

24 Amiral J, Lormean JC, Marfaing-Koka A, et al. Absence of cross-reactivity of SR90107A/ORG31540 pentasaccharide with antibodies to heparin-PF4 complexes developed in heparin-induced thrombocytopenia. Blood Coagul Fibrinolysis 1997; 8: 114-7.

25 Savi P, Chong BH, Greinacher A, et al. Effect of fondaparinux on platelet activation in the presence of heparin-dependent antibodies: a blinded comparative multicenter study with unfractionated heparin. Blood 2005; 105: 139-44.

26 George JN, Raskob GE, Shah SR, et al. Drug-induced thrombocytopenia: a systematic review of published case reports. Ann Intern Med 1998; 129: 886-90.

27 Stephan F, Hollande J, Richard O, Cheffi A, MaierRedelsperger $M$, Flabault $A$. Thrombocytopenia in a surgical ICU. Chest 1999; 115: 1363-70.

28 Warkentin TE, Greinacher A. Heparin-induced thrombocytopenia: recognition, treatment, and prevention: the Seventh ACCP Conference on Antithrombotic and Thrombolytic Therapy. Chest 2004; 126(3 Suppl): 311S-37S.

29 Schrezenmeier H, Muller H, Gunsilius E, Heimpel H, Seifried E. Anticoagulant-induced pseudothrombocytopenia and pseudoleucocytosis. Thromb Haemost 1995; 73: 506-13.

30 Warkentin TE, Kelton JG. Temporal aspects of heparininduced thrombocytopenia. N Engl J Med 2001; 344: 1286-92.

31 Girolami B, Prandoni P, Stefani PM, et al. The incidence of heparin-induced thrombocytopenia in hospitalized medical patients treated with subcutaneous unfractionated heparin: a prospective cohort study. Blood 2003; 101: 2955-9.

32 Rhodes GR, Dixon RH, Silver D. Heparin induced thrombocytopenia with thrombotic and hemorrhagic manifestations. Surg Gynecol Obstet 1973; 136: 40916.

33 Warkentin TE, Kelton JG. A 14-year study of heparininduced thrombocytopenia. Am J Med 1996; 101: 502-7.

34 Warkentin T. Clinical picture of heparin-induced thrombocytopenia. In: Greinacher A (Ed.). HeparinInduced Thrombocytopenia, $2^{\text {nd }}$ ed. New-York-Basel: Marce Dekker, Inc; 2004: 53-106.

35 Tardy B, Tardy-Poncet B, Fournel P, Venet C, Jospe R, Dacosta $A$. Lower limb veins should be systematically explored in patients with isolated heparin-induced thrombocytopenia. Thromb Haemost 1999; 82: 1199200.

36 Greinacher $A$. Treatment of heparin-induced thrombocytopenia. Thromb Haemost 1999; 82: 457-67.

37 Warkentin TE. Heparin-induced skin lesions. Br J Haematol 1996; 92: 494-7.

38 Warkentin TE. Heparin-induced thrombocytopenia: IgG-mediated platelet activation, platelet microparticle generation, and altered procoagulant/anticoagulant balance in the pathogenesis of thrombosis and venous limb gangrene complicating heparin-induced thrombocytopenia. Transfus Med Rev 1996; 10: 249-58.

39 Warkentin TE, Greinacher A. Heparin-induced thrombocytopenia and cardiac surgery. Ann Thorac Surg 2003; 76: 638-48.

40 Warkentin TE, Roberts RS, Hirsh J, Kelton JG. An improved definition of immune heparin-induced thrombocytopenia in postoperative orthopedic patients. Arch Intern Med 2003; 163: 2518-24.

41 Lillo-Le Louet A, Boutouyrie P, Alhenc-Gelas M, et al. Diagnostic score for heparin-induced thrombocytope- 
nia after cardiopulmonary bypass. J Thromb Haemost 2004; 2: 1882-8.

42 Pouplard C, May MA, Regina S, Marchand M, Fusciardi J, Gruel $\Upsilon$. Changes in platelet count after cardiac surgery can effectively predict the development of pathogenic heparin-dependent antibodies. Br J Haematol 2005; 128: 837-41.

43 Amiral J, Meyer D. Heparin-induced thrombocytopenia: diagnostic tests and biological mechanisms. Baillieres Clin Haematol 1998; 11: 447-60.

44 Greinacher A, Amiral J, Dummel V, Vissac A, Kiefel V, Mueller-Eckhardt C. Laboratory diagnosis of heparinassociated thrombocytopenia and comparison of platelet aggregation test, heparin-induced platelet activation test, and platelet factor 4/heparin enzyme-linked immunosorbent assay. Transfusion 1994; 34: 381-5.

45 Warkentin TE, Hayward CP, Smith CA, Kelly PM, Kelton JG. Determinants of donor platelet variability when testing for heparin-induced thrombocytopenia. J Lab Clin Med 1992; 120: 371-9.

46 Pfueller SL, David R. Different platelet specificities of heparin-dependent platelet aggregating factors in heparin-associated immune thrombocytopenia. Br J Haematol 1986; 64: 149-59.

47 Sheridan D, Carter C, Kelton JG. A diagnostic test for heparin-induced thrombocytopenia. Blood 1986; 67: 27-30.

48 Greinacher A, Michels I, Kiefel V, Mueller-Eckhardt C. A rapid and sensitive test for diagnosing heparin-associated thrombocytopenia. Thromb Haemost 1991; 66: 734-6.

49 Tomer $A$. A sensitive and specific functional flow cytometric assay for the diagnosis of heparin-induced thrombocytopenia. Br J Haematol 1997; 98: 648-56.

50 Bachelot-Loza C, Saffroy R, Lasne D, Chatellier G, Aiach M, Rendu F. Importance of the FcgammaRIIaArg/His-131 polymorphism in heparin-induced thrombocytopenia diagnosis. Thromb Haemost 1998; 79: 523-8.

51 Visentin GP, Moghaddam M, Beery SE, McFarland JG, Aster $R H$. Heparin is not required for detection of antibodies associated with heparin-induced thrombocytopenia/thrombosis. J Lab Clin Med 2001; 138: 22-31.

52 Regnault V, de Maistre E, Carteaux JP, et al. Platelet activation induced by human antibodies to interleukin8. Blood 2003; 101: 1419-21.

53 Foblen-Walter A, De Maistre E, Mulot A, MarchandArvier $M$, Lecompte $T$. Does negative heparin-platelet factor 4 enzyme-linked immunosorbent assay effectively exclude heparin-induced thrombocytopenia? J Thromb Haemost 2003; 1: 1844-5.

54 Trossaert M, Gaillard A, Commin PL, Amiral J, Vissac
AM, Fressinaud E. High incidence of anti-heparin/ platelet factor 4 antibodies after cardiopulmonary bypass surgery. Br J Haematol 1998; 101: 653-5.

55 Bawer TL, Arepally G, Konkle BA, et al. Prevalence of heparin-associated antibodies without thrombosis in patients undergoing cardiopulmonary bypass surgery. Circulation 1997; 95: 1242-6.

56 Eichler P, Raschke R, Lubenow N, Meyer O, Schwind P, Greinacher $A$. The new ID-heparin/PF4 antibody test for rapid detection of heparin-induced antibodies in comparison with functional and antigenic assays. Br J Haematol 2002; 116: 887-91.

57 Warkentin TE, Heddle NM. Laboratory diagnosis of immune heparin-induced thrombocytopenia. Curr Hematol Rep 2003; 2: 148-57.

58 Alving BM. How I treat heparin-induced thrombocytopenia and thrombosis. Blood. 2003; 101: 31-7.

59 Warkentin TE, Chong BH, Greinacher A. Heparininduced thrombocytopenia: towards consensus. Thromb Haemost 1998; 79: 1-7.

60 Chong BH. Heparin-induced thrombocytopenia. J Thromb Haemost 2003; 1: 1471-8.

61 Greinacher A, Eichler P, Albrecht D, Strobel U, Potzsch $B$, Eriksson BI. Antihirudin antibodies following low-dose subcutaneous treatment with desirudin for thrombosis prophylaxis after hip-replacement surgery: incidence and clinical relevance. Blood 2003; 101 : 2617-9.

62 Lewis BE, Wallis DE, Berkowitz SD, et al. Argatroban anticoagulant therapy in patients with heparin-induced thrombocytopenia. Circulation 2001; 103: 1838-43.

63 Lewis BE, Wallis DE, Leya F, Hursting MJ, Kelton JG; Argatroban-915 Investigators. Argatroban anticoagulation in patients with heparin-induced thrombocytopenia. Arch Intern Med 2003; 163: 1849-56.

64 Farner B, Eichler P, Kroll H, Greinacher A. A comparison of danaparoid and lepirudin in heparin-induced thrombocytopenia. Thromb Haemost 2001; 85: 9507.

65 Tardy-Poncet B, Tardy B, Reynaud J, et al. Efficacy and safety of danaparoid sodium (ORG 10172) in critically ill patients with heparin-associated thrombocytopenia. Chest 1999; 115: 1616-20.

66 Huble G, Hoffmann U, Song X, Wang LC, Heene DL, Harenberg J. Immunologic response to recombinant hirudin in HIT type II patients during long-term treatment. Br J Haematol 1999; 106: 195-201.

67 Eichler P, Friesen HJ, Lubenow N, Jaeger B, Greinacher $A$. Antihirudin antibodies in patients with heparininduced thrombocytopenia treated with lepirudin: incidence, effects on aPTT, and clinical relevance. Blood 2000; 96: 2373-8.

68 Wilde MI, Markham A. Danaparoid. A review of its 
pharmacology and clinical use in the management of heparin-induced thrombocytopenia. Drugs 1997; 54: 903-24.

69 Greinacher A, Lubenow N. Recombinant hirudin in clinical practice: focus on lepirudin. Circulation 2001; 103: 1479-84.

70 Monagle P, Michelson AD, Bovill E, Andrew M. Antithrombotic therapy in children. Chest 2001; 119: 344S-70S.

71 Potzsch B, Madlener K, Seelig C, Riess CF, Greinacher $A$, Muller-Berghaus $G$. Monitoring of r-hirudin anticoagulation during cardiopulmonary bypass--assessment of the whole blood ecarin clotting time. Thromb Haemost 1997; 77(1 Suppl): 920-5.

72 Poetzsch B, Madlener K. Management of cardiopulmonary bypass anticoagulation in patients with heparininduced thrombocytopenia. In: Greinacher A (Ed.). Heparin-Induced Thrombocytopenia, $2^{\text {nd }}$ ed. NewYork-Basel: Marce Dekker, Inc.; 2001: 429-44.

73 Longrois D, de Maistre E, Bischoff $N$, et al. Recombinant hirudin anticoagulation for aortic valve replacement in heparin-induced thrombocytopenia. Can J Anesth 2000; 47: 255-60.

74 Koster A, Merkle F, Hansen R, et al. Elimination of recombinant hirudin by modified ultrafiltration during simulated cardiopulmonary bypass: assessment of different filter systems. Anesth Analg 2000; 91: 265-9.

75 Magnani H, Beijering R, Ten Cate J, Chong B. Oragran anticoagulation for cardiopulmonary bypass in patients with heparin-induced thrombocytopenia. In: Pifarre R (Ed.). New Anticoagulants for the Cardiovascular Patient. Philadelphia: Hanley and Belfus; 1997: 487500.

76 Antoniou T, Kapetanakis EI, Theodoraki K, et al. Cardiac surgery in patients with heparin-induced thrombocytopenia using preoperatively determined dosages of iloprost. Heart Surg Forum 2002; 5: 3547.

77 Koster A, Kukucka M, Bach F, et al. Anticoagulation during cardiopulmonary bypass in patients with heparin-induced thrombocytopenia type II and renal impairment using heparin and the platelet glycoprotein IIb-IIIa antagonist tirofiban. Anesthesiology 2001; 94: 245-51. 